\title{
Spontaneous rupture of intracranial dermoid cyst in a child
}

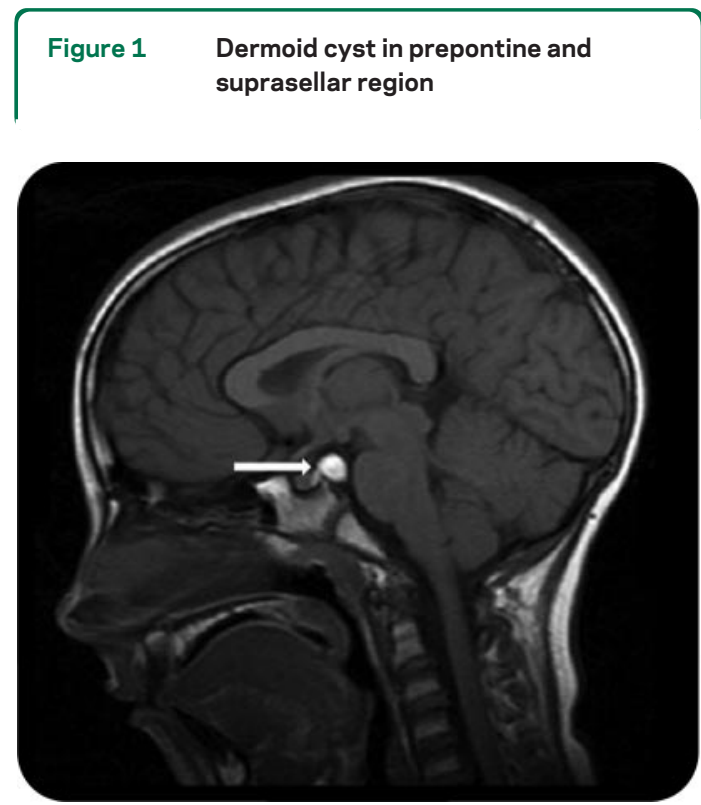

Brain MRI at age 11 years. There is a T1 hyperintense lesion in the prepontine cistern and suprasellar region measuring $11 \mathrm{~mm}$ in the greatest dimension (arrow). The T1 hyperintensity, T2 hypointensity (not shown), and midline position are suggestive of an intracranial dermoid cyst.

\section{Figure 2 Ruptured dermoid cyst}

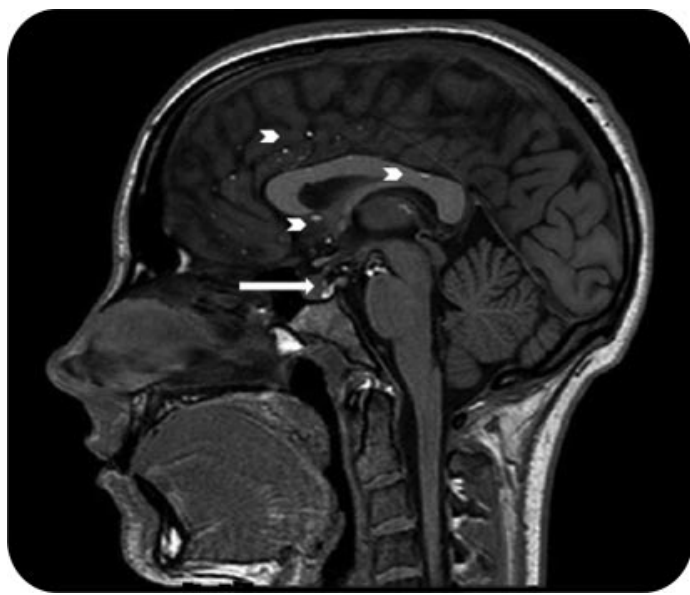

Brain MRI at age 15 years. There is a $14 \times 16 \times 11 \mathrm{~mm}$ lobulated T1 hyperintense mass within the prepontine cistern extending into the suprasellar cistern (arrow). There are punctate foci of T1 hyperintensity (arrowheads) disseminated throughout the subarachnoid space suggestive of ruptured dermoid cyst. The patient was diagnosed with aseptic meningitis secondary to rupture of dermoid cyst. She was managed conservatively. At follow-up 2 years after rupture, there were no new symptoms and no change in cyst size.

A 17-year-old girl was diagnosed at age 3 with a suprasellar dermoid cyst following complaints of headaches. At 15, headache worsened, with nausea, vomiting, and confusion. Headache was sudden, severe, and pressure-like. Repeat brain MRI showed rupture of the dermoid cyst into the subarachnoid space (figures 1 and 2).

Rupture of dermoid cysts is rare and usually spontaneous, although trauma-related rupture may occur. The hypothesized mechanism of rupture is rapid enlargement of the cyst due to age-dependent hormonal changes. ${ }^{1}$ The presenting clinical features of rupture can vary from none to headache, seizures, chemical meningitis, cerebral ischemia with motor, sensory, or visual deficits, and hydrocephalus. ${ }^{2}$

\section{Shalaka Indulkar, $M D$, Gary E. Hsich, $M D$, Cleveland, $\mathrm{OH}$}

Author contributions: Dr. Indulkar: drafting the manuscript. Dr. Hsich: conceptualization of the report.

Disclosure: The authors report no disclosures.

Address correspondence and reprint requests to Dr. Shalaka Indulkar, Department of Pediatric Neurology, S60, Cleveland Clinic Foundation, 9500 Euclid Avenue, Cleveland, OH 44195; indulks@ccf.org

1. Stendel R, Pietila TA, Lehmann K, et al. Ruptured intracranial dermoid cysts. Surg Neurol 2002;57:391-398.

2. Liu JK, Gottfried ON, Salzman KL, Schmidt RH, Couldwell WT. Ruptured intracranial dermoid cysts: clinical, radiographic, and surgical features. Neurosurgery 2008;62:377-384. 


\section{Neurology}

\section{Spontaneous rupture of intracranial dermoid cyst in a child Shalaka Indulkar and Gary E. Hsich \\ Neurology 2011;77;2070 \\ DOI 10.1212/WNL.0b013e31823b479f}

\section{This information is current as of December 5, 2011}

\section{Updated Information \& Services}

References

Citations

Subspecialty Collections

Permissions \& Licensing

Reprints including high resolution figures, can be found at: http://n.neurology.org/content/77/23/2070.full

This article cites 2 articles, 0 of which you can access for free at: http://n.neurology.org/content/77/23/2070.full\#ref-list-1

This article has been cited by 1 HighWire-hosted articles: http://n.neurology.org/content/77/23/2070.full\#\#otherarticles

This article, along with others on similar topics, appears in the following collection(s):

\section{All Headache}

http://n.neurology.org/cgi/collection/all_headache

\section{MRI}

http://n.neurology.org/cgi/collection/mri

Primary brain tumor

http://n.neurology.org/cgi/collection/primary_brain_tumor

Information about reproducing this article in parts (figures,tables) or in its entirety can be found online at:

http://www.neurology.org/about/about_the_journal\#permissions

Information about ordering reprints can be found online: http://n.neurology.org/subscribers/advertise

Neurology ${ }^{\circledR}$ is the official journal of the American Academy of Neurology. Published continuously since 1951, it is now a weekly with 48 issues per year. Copyright Copyright (? 2011 by AAN Enterprises, Inc.. All rights reserved. Print ISSN: 0028-3878. Online ISSN: 1526-632X.

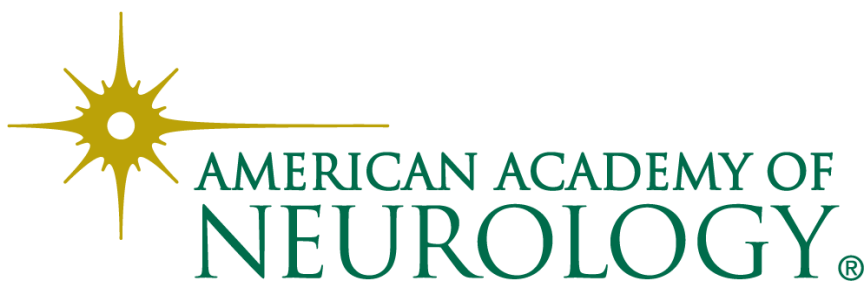

